\title{
Influence of the Quality of Maintenance of Fish Ponds on the Biomass of Zooplankton in situ in Tropical Zone (Yaoundé-Cameroon-Central Africa)
}

\section{Jeannette Prudence Dakwen, Serge Hubert Zebaze Togouet*, Sylvie Belengfe Chinche, Olive Vivien Noah Ewoti, Mireille Kapso Tchouankep, Thomas Njine}

Department of Animal Biology and Physiology, Faculty of Science, University of Yaoundé I, Yaoundé, Cameroun

\section{Email address:}

zebasehu@yahoo.fr (S. H. Z. Togouet)

${ }^{*}$ Corresponding author

\section{To cite this article:}

Jeannette Prudence Dakwen, Serge Hubert Zebaze Togouet, Sylvie Belengfe Chinche, Olive Vivien Noah Ewoti, Mireille Kapso Tchouankep, Thomas Njine. Influence of the Quality of Maintenance of Fish Ponds on the Biomass of Zooplankton in situ in Tropical Zone (Yaoundé-Cameroon-Central Africa). International Journal of Natural Resource Ecology and Management. Vol. 4, No. 3, 2019 , pp. 62-72. doi: 10.11648/j.ijnrem.20190403.11

Received: April 30, 2019; Accepted: June 12, 2019; Published: June 26, 2019

\begin{abstract}
A comparative study of the biomass of zooplankton of four semi-intensive fish ponds found in the ecological area of Yaoundé in Cameroon was sampled for 9 months, which made it possible to evaluate the influence of the maintenance quality of the water bodies on their productivity. There were three ponds E1, E2, and E3 fertilized with organic and mineral matter, sampled from March to November 2012 on the one hand and on the other hand an experimental pond ET serving as a control, which was sampled from March to November 2014. ET was fertilized with mineral and organic matter and received particular attention during the first three months of breeding. The breeding method recommended in these ponds was the polyculture of Clarias gariepinus and Oreochromis niloticus. The samples were collected twice a month at $20 \mathrm{~cm}$ depth. Physico-chemical and biological analyses were measured using appropriate techniques. Zooplankton biomass remained very high in ET relative to E1, E2 and E3 (90\% vs. 10\%), creating an uneven profile in all water bodies. Minimum biomass values were $119 \mathrm{mg} \mathrm{C} / \mathrm{L}$ in E1, $200 \mathrm{mg} \mathrm{C} / \mathrm{L}$ in E2, $40 \mathrm{mg} \mathrm{C} / \mathrm{L}$ in E3 and $781 \mathrm{mg} \mathrm{C} / \mathrm{L}$ in ET; the maximum values being $748 \mathrm{mg}$ C / L, $2643 \mathrm{mg} \mathrm{C} \mathrm{/} \mathrm{L,} 474 \mathrm{mg} \mathrm{C} / \mathrm{L}$ and $67010 \mathrm{mg} \mathrm{C} / \mathrm{L}$ in E1, E2, E3 and ET respectively. The largest contributors to this biomass were rotifers followed by Cladocerans in ET and E2 and Copepods followed by rotifers in E1 and E3. Food resources were thus limited in these last two water bodies compared to others. Abiotic and biological analyses indicate that these water bodies were oligomesotrophic (E1 and E3), mesotrophic (E2) and eutrophic (ET). ET under these conditions enabled the production of a satisfactory fish yield. It is therefore recommended that, fish farmers should improve the quality of maintenance of fish ponds which together with good fertilization will generate maximum productivity.
\end{abstract}

Keywords: Semi-intensive Fish Pond, Biomass, Zooplankton, Quality of Maintenance

\section{Introduction}

Zooplanktons are an important component in the structuring and functioning of pond ecosystems [1]. Through their browsing mode, these organisms form an essential trophic link between primary producers and higher trophic level organisms [2]. The rate of transfer of primary lake products by zooplankton to fish fry can be more than $60 \%$ the amount of energy transferred which is depended on the weight of the organisms consumed [3]. Zooplankton is thus, the most important source of protein to fries, planktivorous and omnivorous fish [4-5]. In addition, these organisms are sensitive to variations to environmental conditions and are excellent indicators of pollution [6]. These organisms therefore occupy a prominent place in the ecology of fish ponds; moreover, it has been shown that Agricultural Exploitation by Families (AEF) must take into account fish farming to maximize their yield [7-8]. Also, the development 
of fish farming would not only cover huge animal protein needs but would also reduce the massive outflow of foreign exchange [9]. However, Cameroon like several middleincome countries, has been working with FAO for more than 15 years to develop the "fish farming industry" which aims in the fight against poverty, and to close the deficit in animal protein [10]. The numerous recorded failures led to a questioning on the piscicultural practice and to seek ways and means to increase the yields [11-13]. Knowledge of the biomass of zooplanktons in small water points is needed to develop an effective management strategy for these environments [14-17]. Despite these works, information on the use of zooplanktonic biomass for assessing the impact for maintenance quality on productivity of fish ponds has rarely been elucidated and data concerning these aspects are scarce. zooplankton community (Rotifers, Cladocerans and Copepods) in four fish ponds including three peasant ponds (E1, E2 and E3) and an experimental pond (ET), located in Ekoumdoum - Yaounde; in relation to some physicochemical variables of the environment as well as the impact of the quality of maintenance accorded to the water body by these parameters.

\section{Material and Methods}

\subsection{Study Site}

The study area is located at Yaoundé 4 subdivision between latitudes $3^{\circ} 48^{\prime} 45^{\prime \prime}$ and $3^{\circ} 49^{\prime} 15^{\prime \prime} \mathrm{N}$ and longitudes $11^{\circ} 31^{\prime} 45^{\prime \prime}$ and $11^{\circ} 32^{\prime} 10^{\prime \prime} \mathrm{E}$ (figure 1).

This present work examines the biomass of the

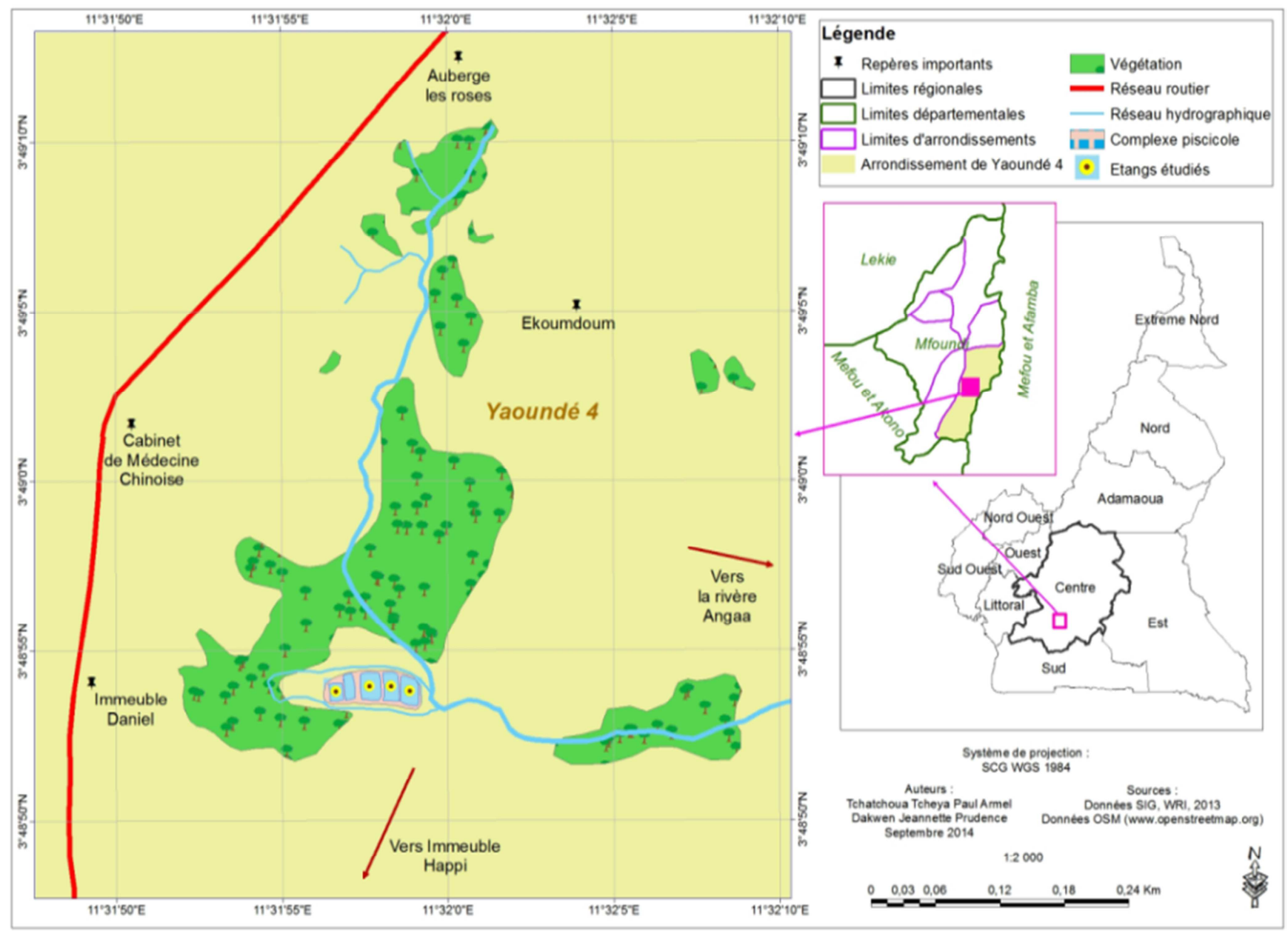

Figure 1. Study site map.

\subsection{Sampling Stations (Fish Pond)}

The quality of maintenance of fish ponds include; stock, fertilization, monitoring during the breeding cycle/daily routine control (penetration of light into the water, behavior of fish in the early morning, state of the pond banks and channels of supply/discharge of water, control of hardness) so as to rapidly intervene in case of problems [18]. The sampled water bodies were selected in a private fish farm called G.I.C. AGROELEVEUR. This farm presents two categories of ponds:

- Ponds E1, E2 and E3 called "peasant-ponds" measured less than $500 \mathrm{~m}^{2}$ and about $70 \mathrm{~cm}$ deep which were maintained by the head staff of G.I.C. who sometimes use his family members as manpower (wife, sister-in-law and two children). Pond E1 has three intra-pond organic fertilizer made from elephant grass Pennisetum purpureum 
supplemented with pig manure. Pond E2 has a pigsty built on stilts, containing four pigs of about $60 \mathrm{~kg}$ each fed daily with 40 liters of slurry. Pond E3 has three intra-pond composts and is fertilized with droppings from "broilers". Each of these water bodies received fingerling at a ratio of 2 tilapia and 2 catfish per $\mathrm{m}^{2}$. The farmer ensures the routine control and intervenes in case of problem when the needed.

-The experimental pond ET, which is $98 \mathrm{~m}^{2}$ by $80 \mathrm{~cm}$ deep at the level of the monk is surrounded by a fence protecting it against unwanted animals and has a pigsty built on piles containing a pig of about $80 \mathrm{~kg}$. It was stocked with 1 Oreochromis niloticus and 2 Clarias gariepinus. The fish farmer ensures daily routine control (penetration of light into the water, behaviour of fish in the early morning, state of the banks and channels of supply and discharge of water, control of water hardness) and intervenes quickly in case of problems.

\subsection{Data Collection}

The key ecological attributes that were used to assess the impact of maintenance on the ponds on zooplankton biomass were abiotic and biotic (biomass variation) factors [18]. For the abiotic factors, the indicators considered were temperature, water transparency, $\mathrm{pH}$, calcium hardness $\left(\mathrm{Ca}^{++}\right)$, alkalinity, dissolved Oxygen $\left(\mathrm{O}_{2}\right)$, Suspended Solid (SS), turbidity, ammonium ions $\left(\mathrm{NH}_{4}^{+}\right)$and orthophosphates $\left(\mathrm{PO}_{4}{ }^{3-}\right)$ [19]. Collection of samples to measure these indicators was performed using $1000 \mathrm{cc}$ polyethylene bottles in $1 \mathrm{~m} \times 1 \mathrm{~m}$ quadrats randomly selected at $20 \mathrm{~cm}$ depth from the monk twice a week [18-19]. The measurement of these indicators was done in situ and in the laboratory according to standard techniques [18].

Sampling for the monitoring of zooplankton biomass was carried out following the same step and following the protocol recommended by these studies [17-18]. Indeed, the biological samples were collected by filtration of 50 liters of water through a sieve of $64 \mu \mathrm{m}$ mesh size. The organisms collected were kept in $200 \mathrm{cc}$ of water from the milieu. A first half $(100 \mathrm{cc})$ of this subsample was fixed by adding formalin up to $5 \%$ for identification, counting and measurements while the second half $(100 \mathrm{cc})$ was used for observation of living organisms [14, 20].

The faunistic study was carried out using a binocular stereo microscope of the mark WILD M5 and the OLYMPUS CK2 UL WCD 0.30 microscope for identification, counting and measurements of Rotifer, Cladocera and Copepod species. The identification was carried out using identification keys of [17, 21, 22] for Rotifers; [17, 22, 23] for Copepods and Cladocera. Counting was done by duplicate counting in $30 \mathrm{~mm}$ diameter Petri dishes crisscrossed into small $3 \mathrm{~mm}$ squares [24]. At least 100 individuals was counted each time per sample or the count continues until the sample was exhausted. The density of the individuals in the sample was calculated using the following formula:

$$
\mathrm{D}=\frac{v}{v^{\prime} . V} \times n \text { expressed in ind. } / \mathrm{L}
$$

With: $v=$ total volume of the subsample; $v^{\prime}=$ volume of the subsample fraction poured into the Petri dish for counting; $V=$ volume of filtered water in the field; $n=$ number of individuals contained in $v^{\prime}$.

Bio volumes obtained by measurement [25] are multiplied by the density of each species and converted into biomass [26] using the following formula:

$$
10^{6} \mu \mathrm{m}^{3} \mathrm{~L}^{-1}=1 \mu \mathrm{gC} \mathrm{L}{ }^{-1} .
$$

\subsection{Data Analysis}

The rank correlation of Spearman made it possible to evaluate within the same water body, the level of dependence between physicochemical variables and between biological and physico-chemical variables. To highlight the influence of the quality of maintenance performed by the farmer on the physicochemical parameters on water and on zooplankton biomass, Kruskall Wallis analysis followed by the Mann Whitney test were used to compare the fish pond data.

\section{Results}

\subsection{Abiotic Factors}

Figures 2 and 3 show the spatio-temporal variation of the physicochemical parameters in the four ponds. The average temperature of pond water generally remained very stable around $25^{\circ} \mathrm{C}$ during the complete cycle of breeding (between $23^{\circ} \mathrm{C}$ and $26^{\circ} \mathrm{C}$ for $\mathrm{E} 1,23^{\circ} \mathrm{C}$ and $25^{\circ} \mathrm{C}$ for $\mathrm{E} 2,24.5^{\circ} \mathrm{C}$ and $27.5^{\circ} \mathrm{C}$ for $\mathrm{E} 3$ and $20^{\circ} \mathrm{C}$ and $40^{\circ} \mathrm{C}$ for $\mathrm{ET}), \mathrm{E} 3$ being the coldest pond and ET being the hottest pond (figure 2A). The values of Suspended Solids (SS) varied little in E1 and E2 which an average of $18.5 \mathrm{mg} / \mathrm{L}$ and $14.8 \mathrm{mg} / \mathrm{L}$ respectively. These values varied from 0 to $48 \mathrm{mg} / \mathrm{L}$ in E3 and 1 to $112 \mathrm{mg} / \mathrm{L}$ in ET. The values of SS obtained in E3 pond and ET showed significant variations $(\mathrm{P}<0.05)$, with ET richer in SS (figure 2B). Turbidity oscillated between 30 and 56 FTU in E1, 17 and 67 FTU in E2, 14 and 60 FTU in E3 and 0 and 174 FTU in ET; this last pond was more turbid, most of the time (figure 2C). The depth of disappearance of the Secchi disc varied significantly in the various ponds during this study $(\mathrm{P}<$ $0,05)$; extreme values were 17,5 and $31,5 \mathrm{~cm}$ for E1, 25 and $45 \mathrm{~cm}$ for E3, 12 and 25,5 cm for E2 and ET. The last pond was the least transparent pond (figure 2D). 

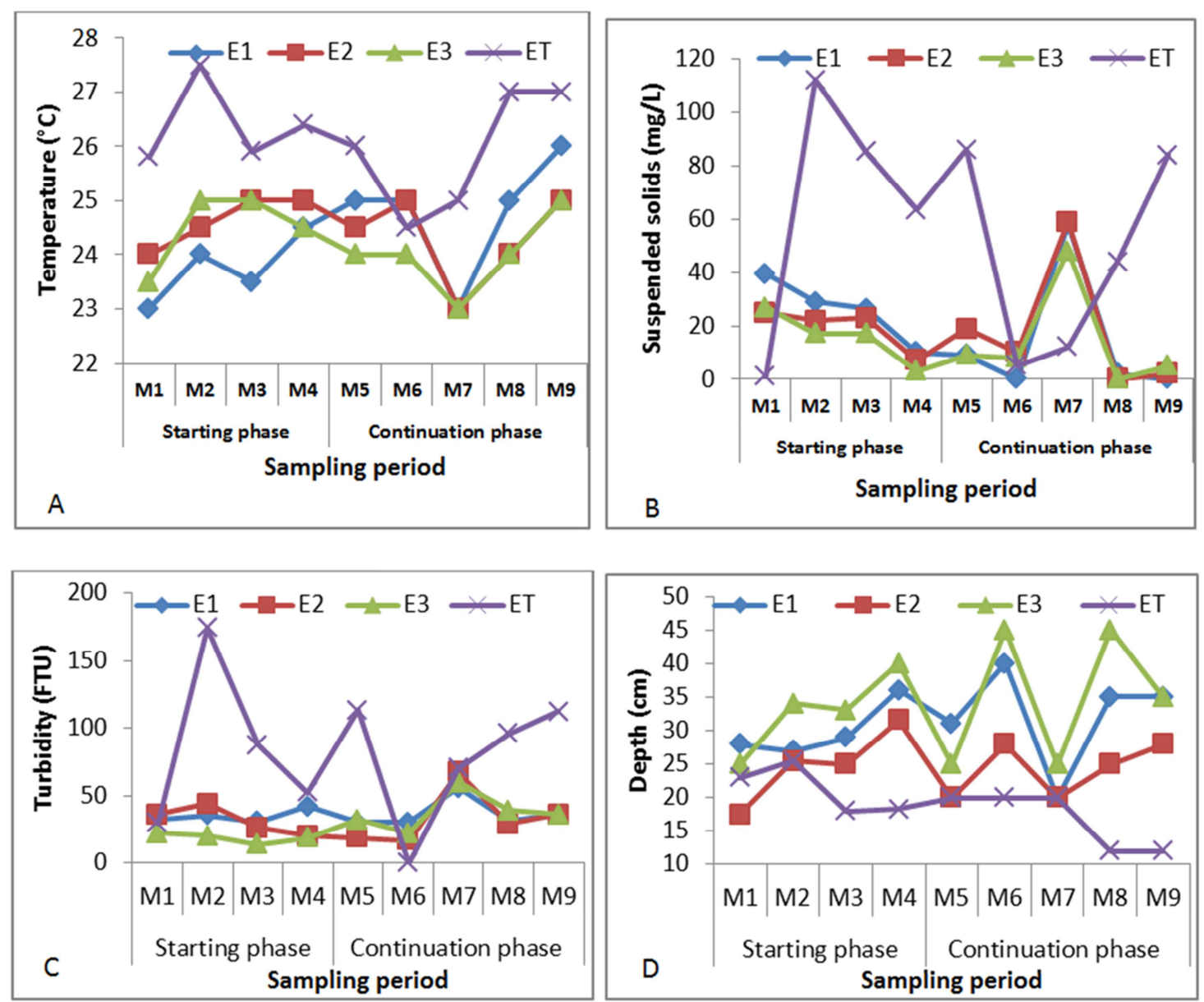

Figure 2. Spatio-temporal variation of physical variables: temperature (A), Suspended Solids (B), Turbidity (C) and Transparency (D) during the work period with $E 1=$ Pond $E 1, E 2=$ pond $E 2, E 3=$ pond $E 3, E T=$ pond $E T$ and $M=$ month.

Water of the studied ponds was slightly acidic except during the first three months of breeding in ET where water remained basic. The average values of $\mathrm{pH}$ was $6.5 \mathrm{CU}$ for ponds $\mathrm{E} 1$ and $\mathrm{E} 2$; $6.4 \mathrm{CU}$ for pond $\mathrm{E} 3$ and $6.7 \mathrm{CU}$ for pond ET with a peak $\mathrm{pH}$ of $7.5 \mathrm{CU}$ was obtained in the peasant ponds during the seventh month of breeding (figure $3 \mathrm{~A}$ ). The average values of total alkalinity was $38.3 \mathrm{mg} / \mathrm{L}, 40.6 \mathrm{mg} / \mathrm{L}$, $33.7 \mathrm{mg} / \mathrm{L}$ and $61.7 \mathrm{mg} / \mathrm{L}$ respectively in ponds $\mathrm{E} 1$, E2, E3 and ET. The experimental pond showed values higher

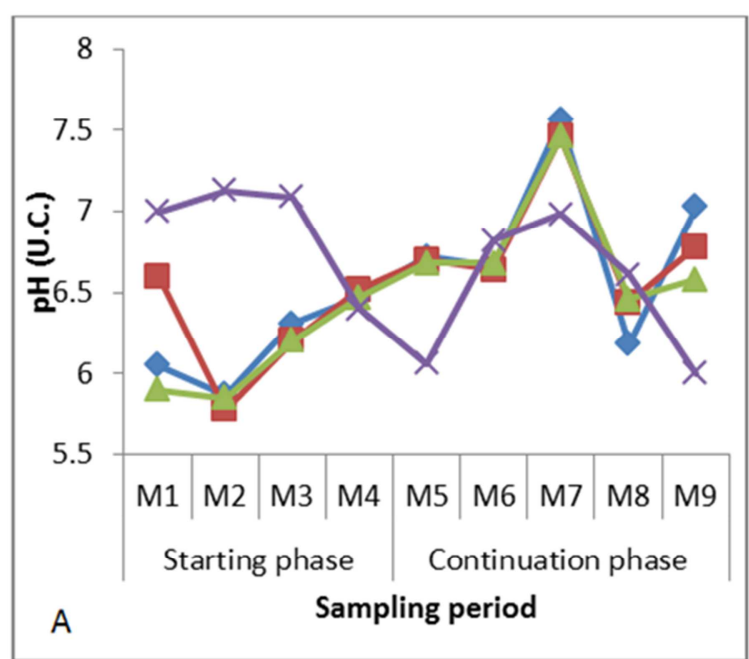

than $60 \mathrm{mg} / \mathrm{L}$ during the four first months of breeding (figure 3B). The average values of calcic hardness were $5.2 \mathrm{mg} / \mathrm{L}, \quad 6.6 \mathrm{mg} / \mathrm{L}, \quad 5.6 \mathrm{mg} / \mathrm{L}$ and $15.11 \mathrm{mg} / \mathrm{L}$ respectively in E1, E2, E3 and ET. However, during the first four months of breeding, the values remained very high (higher than $15 \mathrm{mg} / \mathrm{L}$ ) in ET compared to those of the peasant ponds. As from the fifth month to the end of the breeding cycle, calcic hardness remained low in all the studied ponds (figure 3C).

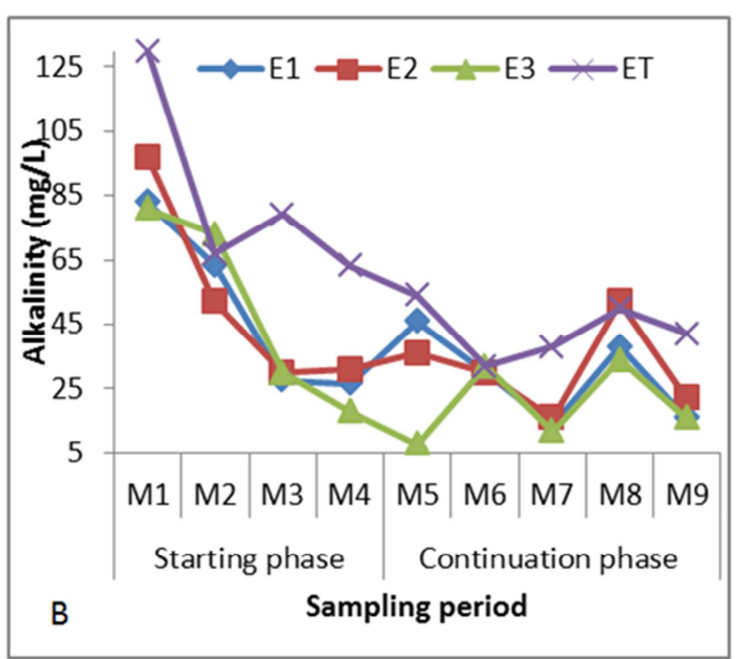



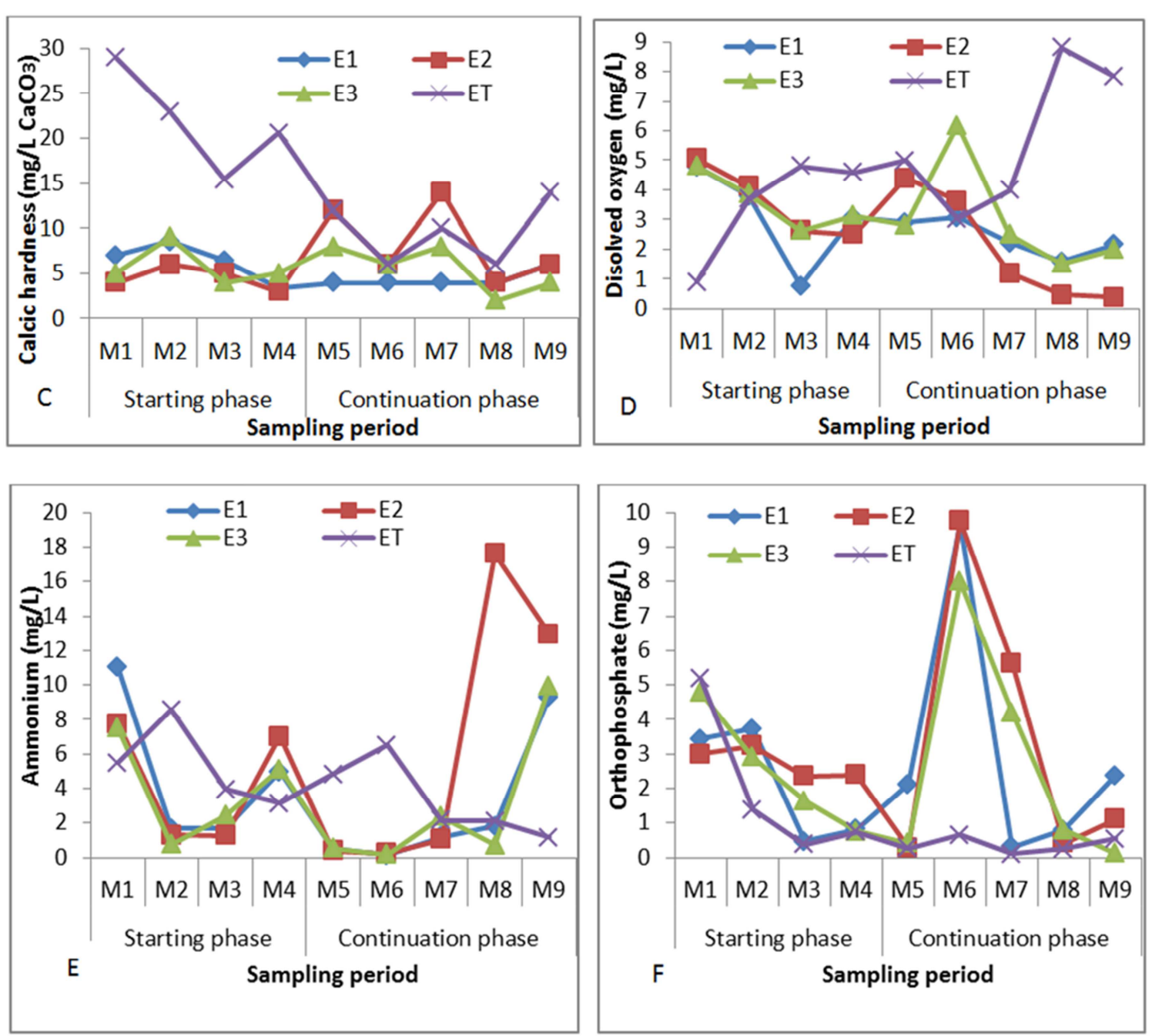

Figure 3. Spatio-temporal variation of chemical variables:pH (A), Total alkalinity (B) Calcic hardness (C), Dissolved oxygen (D), Ammonium (E) and Orthophosphate $(F)$ during the work period with E1 = Pond E1,E2 = pond E2, E3 = pond E3, ET = pond ET and $M=$ month.

Dissolved oxygen (figure 3D) varied very little in the various ponds during the study period, the average values remained lower than $4 \mathrm{mg} / \mathrm{L}$ in the peasant ponds $(2.7 \mathrm{mg} / \mathrm{L}$ in $\mathrm{E} 1$ and $\mathrm{E} 2,3.2 \mathrm{mg} / \mathrm{l}$ in E3) contrary to ET with an average of $4.7 \mathrm{mg} / \mathrm{L}$. Ammonium contents (figure $3 \mathrm{E}$ ) of the studied ponds were in most cases high (higher than $2 \mathrm{mg} / \mathrm{L}$ ) and underwent abrupt variations during the first three months of breeding, especially in the experimental pond (ET). The average values remained between $3.4 \mathrm{mg} / \mathrm{L}$ (E3) and 8.5 $\mathrm{mg} / \mathrm{L}$ (ET). For orthophosphate (figure $3 \mathrm{~F}$ ), its contents in water was generally higher than $2 \mathrm{mg} / \mathrm{L}$ in the peasant ponds with a remarkable peak in the sixth month of breeding (approximately $9 \mathrm{mg} / \mathrm{L}$ ), contrary to ET where the contents are lower than $2 \mathrm{mg} / \mathrm{L}$ except for the value of $5.17 \mathrm{mg} / \mathrm{L}$ recorded in the first month of breeding.

The Spearman correlation tests realized on all the data of each pond showed several interferences. In E1, strong negative correlations $(\mathrm{p}<0.01)$ between temperature and SS, SS and transparency and positive correlations $(\mathrm{p}<0.05)$ between alkalinity and $\mathrm{pH}$ were recorded. In pond E2 the complete cycle of breeding recorded 4 correlations; A negative correlation at $\mathrm{p}<0.01$ between $\mathrm{pH}$ and calcic hardness, positive correlations at $\mathrm{p}<0.05$ between transparency and temperature, $\mathrm{pH}$ and calcic hardness and oxygen and SS. In E3, there was a strong negative correlation $(p<0.01)$ between transparency and SS and a strong positive correlation between $\mathrm{pH}$ and alkalinity $(\mathrm{p}<0.01)$. As for ET, 5 correlations were recorded. They are, negative correlations $(\mathrm{p}<0.05)$ between transparency and temperature, transparency and SS, total alkalinity and calcic hardness, and positive correlations at $\mathrm{p}<0.05$ between SS and dissolved oxygen and calcic hardness and $\mathrm{pH}$.

\subsection{Biological Factors}

\subsubsection{Specific Richness and Abundance}

Sixty one (61) zooplankton species were collected during this study. The total number of rotifer species was 51 belonging to 16 families. The most represented families were those of Brachionidae with 13 species followed by those of Philodinidae with 4 species. The families of Mytilinidae, Hexarthriidae and Euchlanidae were represented by only one species each. However, the most frequent species (figure 4) with more than $70 \%$ were Brachionus angularis, Polyarthra 
vulgaris, Rotaria rotaria, Asplanchna brightwelli and Brachionus calyciflorus in all the ponds. There was an addition of Anuraeopsis fissa for E1, Epiphanes macrourous for E2 and ET, Brachionus quadridentatus for E3 and Filinia longiseta for ET. With regards to Cladocera, except for
Moinidae, 4 families represented by one specie were collected and among those, the frequent species with more than $70 \%$ were Diaphanosoma volzi in E2 and Moina micrura in E1, E2 and ET.

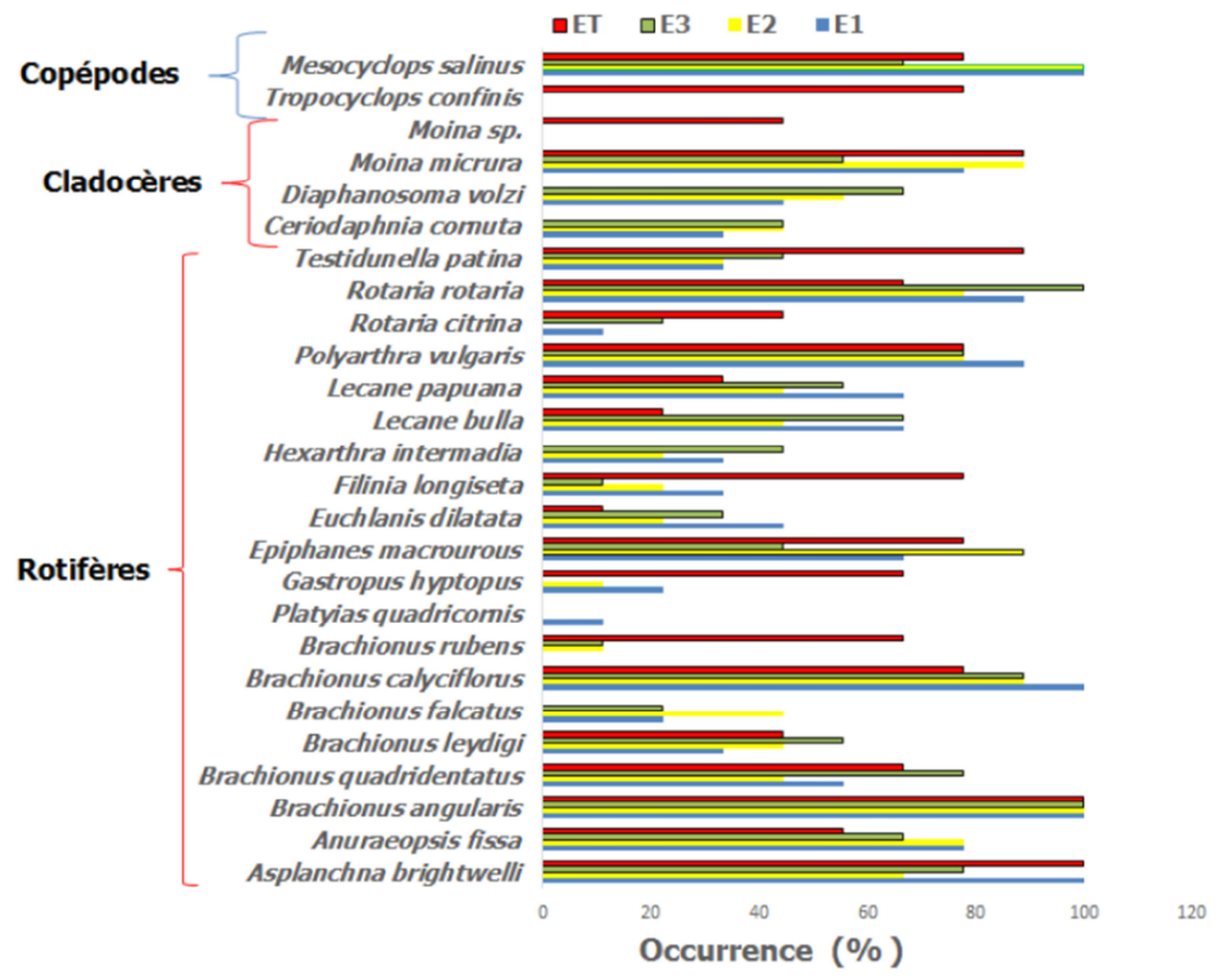

Figure 4. Diagram showing the most frequent species collected in the ponds (at least $40 \%$ of occurrence in at least one pond).

Concerning Copepods, there were 4 species of the family of Cyclopoida. Among them, only 2 species showed at least $40 \%$ of occurrence and Mesocyclops salinus showed a rate of occurrence of more than $70 \%$ in E1, E2 and ET. The Nauplius larvae were collected with more than $70 \%$ in each pond.

A total of 22514 individuals were counted during all the breeding cycle with an average representativeness of $65 \%$ for the experimental pond (ET), 16\% for pond E2, 11\% for pond $\mathrm{E} 1$ and only $8 \%$ for pond E3 (figure $5 \mathrm{~A}$ ). With regards to the spatial contribution of zooplanktonic taxa, (figure 5B) with the total abundance described above, rotifers were most contributive in all the ponds, with at least $67 \%$ (1268 ind./L in E3) of abundance, the least contributive taxon was Copepoda with at most $9 \%(282 \mathrm{ind} / \mathrm{L}$ in E2) in the peasant ponds and $2 \%$ (362 ind./L) in ET. In other words, the abundance of the zooplankton recorded in ET was largely higher than that collected in all the three country ponds.

The spatio-temporal variation profiles (figure 5C) of the total abundance of zooplankton showed a saw teeth form in pond ET and E2. Contrary observations were made in ponds
E1 and E3 where the abundance profiles were linear and almost constant. Indeed, ET presented peaks at the first month of breeding (nearly 2500 ind./L) in the third month (nearly 2000 ind./L), in the fifth month (nearly 3000 ind./L) and in the seventh month (more than 2000 ind./L). Pond E2 also showed slight peaks in the first month (836 ind./L) and during the third month of breeding (average 500 ind./L). However, during the study, the minimum values of abundances were 149 ind./L in E1, 190 ind./L in E2, 82 ind./L in E3 and 242 ind./L in ET; maximum values being $553 \mathrm{ind} / \mathrm{L}, 836$ ind./L, 298 ind./L and 2913 ind./L respectively in E1, E2, E3 and ET. It should be noted that rotifers were dominant on the spatiotemporal level.

Comparison test showed high significant difference $(\mathrm{p}<$ 0,001) of abundances between E1 and ET, between E3 and ET, where the difference is due to rotifers and Cladocerans. In the same way, a significant difference $(\mathrm{P}<0.05)$ of total abundance between E2 and E3, E2 and ET. This difference was mainly due to rotifers. 

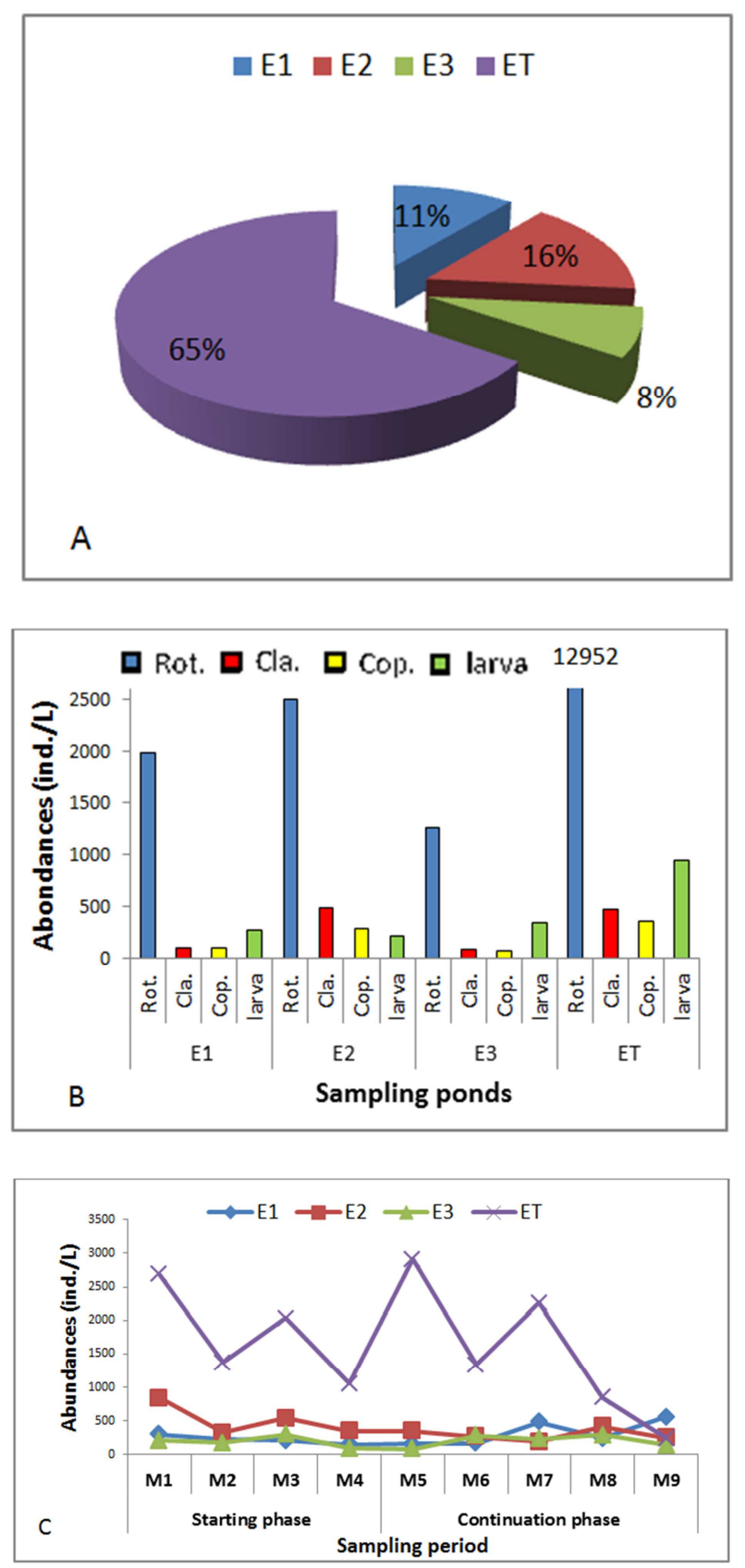

Figure 5. Spatial repartition of the total zooplankton abundances registered during the complete cycle of breeding (A), spatial distribution (B) spatiotemporal distribution $(C)$ of abundances, with $E 1=$ Pond $E 1, E 2=$ pond $E 2$, $E 3=$ pond $E 3, E T=$ pond $E T$ and $M=$ month.

\subsubsection{Zooplankton Biomass}

Zooplankton organisms collected in this study were high in pond ET for rotifers and very small for copepods (Mesocyclops salinus for example) compared to organisms collected in the peasant ponds. For the total biomass (110867.4 $\mathrm{mg} \mathrm{C} / \mathrm{L}$ ) of organisms collected during the complete breeding cycle, Figure $6 \mathrm{~A}$ reveals that only $10 \%$ of this biomass was collected in all peasant ponds. Regarding the spatial contribution of zooplankton taxa (Figure $6 \mathrm{~B}$ ) to the total biomass described above, rotifers dominated only in E2 $(52.7 \%)$ and in ET $(95.7 \%)$, copepods being the largest contributors in E1 (45.5\%) and E3 (51.8\%). For micro crustaceans, Copepods contributed more in the biomass than Cladocerans in E1 (45.5\% vs. $14 \%$ ) and E3 (51.8\% vs. $7.9 \%)$, whereas the opposite is observed in E2 (18, $4 \%$ vs. $27.1 \%)$ and ET $(1.3 \%$ vs. $2.5 \%)$. The spatiotemporal variation profile of the total zooplankton biomass is saw-toothed like in pond ET, which exhibits biomass peaks during the first month of rearing (near $67010 \mathrm{mg} \mathrm{C} / \mathrm{L}$ ), in the third month (4768 mg C / L), and in the fifth month $(11420 \mathrm{mg} \mathrm{C} / \mathrm{L})$. With an exception of the first month of rearing $(2643 \mathrm{mg} \mathrm{C} / \mathrm{L})$ in pond $\mathrm{E} 2$, the biomass profiles are linear and almost constant, no biomass value exceeding $1000 \mathrm{mg} \mathrm{C} / \mathrm{L}$ (Figure 6C) was obtained. However, during the complete rearing cycle, the minimum biomass values were $119 \mathrm{mg} \mathrm{C} / \mathrm{L}$ (third month) in E1, 200 $\mathrm{mg} \mathrm{C} / \mathrm{L}$ (sixth month) in E2, $40 \mathrm{mg} \mathrm{C} / \mathrm{L}$ (second month) in $\mathrm{E} 3$ and $781 \mathrm{mg} \mathrm{C} / \mathrm{L}$ (nine th month) in ET; the maximum values being $748 \mathrm{mg} \mathrm{C} / \mathrm{L}, 2643 \mathrm{mg} \mathrm{C} / \mathrm{L}, 474 \mathrm{mg} \mathrm{C} / \mathrm{L}$ and $67010 \mathrm{mg} \mathrm{C} / \mathrm{L}$ respectively in E1, E2, E3 and ET.

The overall abundance and biomass recorded during this study shows that Rotifers are the most numerous compared to other zooplankton taxa studied, but contribute very strongly to zooplankton biomass only in ponds E2 and ET where they are assisted by Cladocerans. However, in E1 and E3, Copepods were seconded by rotifers which contribute more to the biomass than Cladocerans although these taxa have similar abundances in the said waterbodies. However, the comparison tests show that there is no significant difference in biomass between E3 and E1 and that the difference in biomass between E2 and ET is significant $(p<0.05)$ only for copepod larvae.
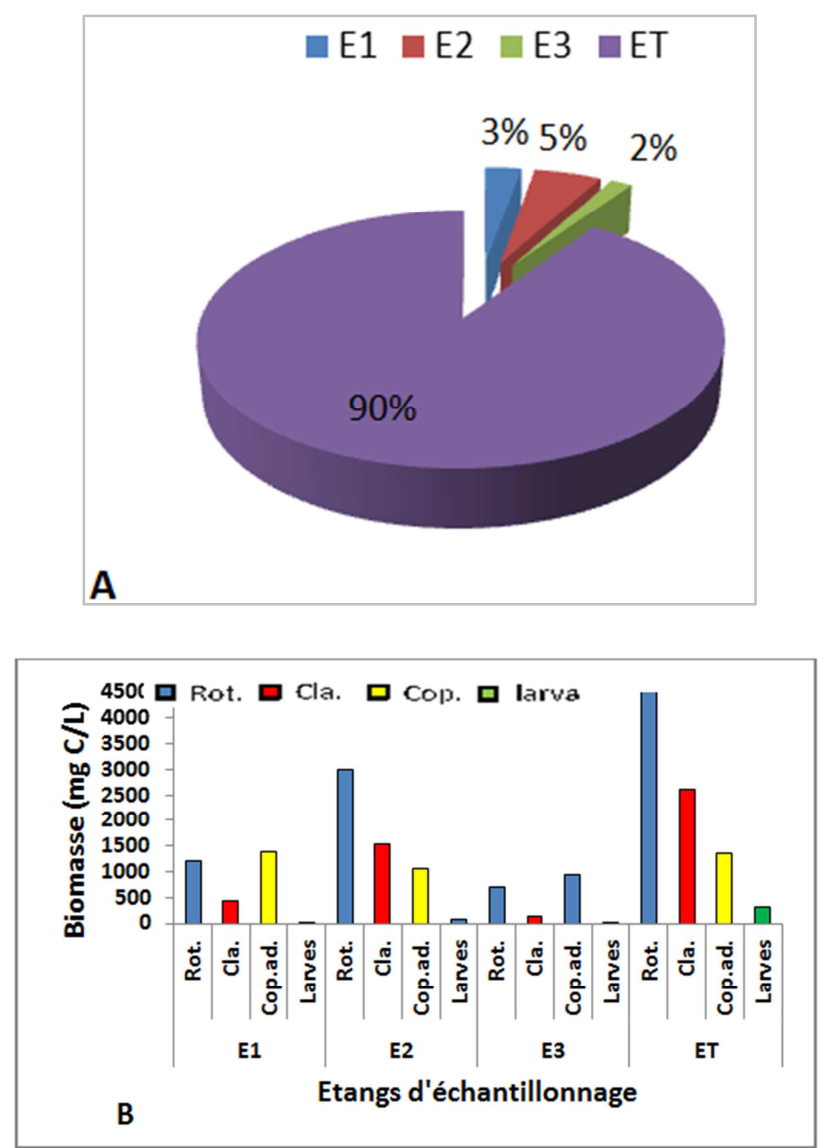


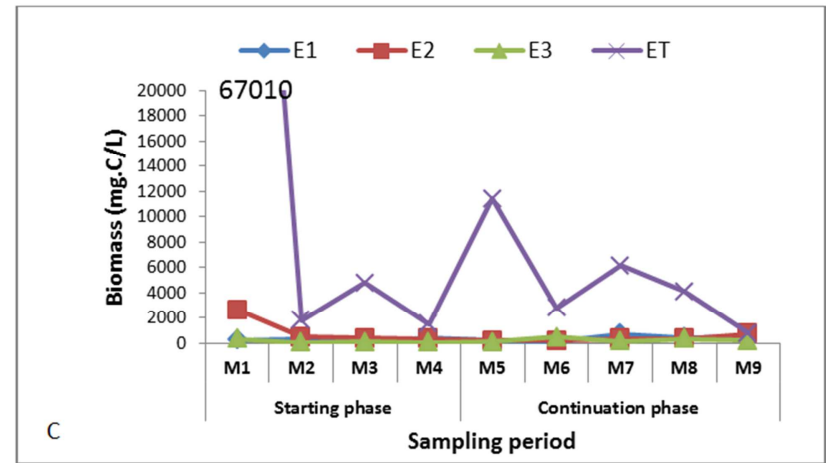

Figure 6. Spatial repartition of total zooplanktonic biomass registered during the complete breeding cycle (A), spatial distribution (B) and spatiotemporal distribution $(C)$ of the biomasses, with $E 1=$ Pond E1, E2 = pond E2, E3 = pond E3, ET = pond ET and $M=$ month.

\section{Discussion}

During the complete cycle, the temperature ranged between $23-26^{\circ} \mathrm{C}$ for the peasant ponds and $24.5-27.5^{\circ} \mathrm{C}$ for ET. These values were close to those recorded in the Yaounde Municipal Lake [27], and in the Simbock-Yaounde fish ponds $[14,20]$. They are typical of small shallow tropical lakes such as Lake George in Uganda [28]. These temperature values are favorable for the optimal growth of fish and especially for the growth of tilapia and catfish [2930]. Mean turbidity and SS values observed in ponds were generally low. In pond ET they remained above 86 FTU and $54 \mathrm{mg} / \mathrm{L}$. The Secchi disk transparency was high. It means that the peasant ponds were poorer in nutrients than pond ET $[14,29]$. Regardless of the water body, an overall positive correlation between values of turbidity and SS were obtained. Negative correlations between these same parameters and transparency were also noted. In fact, in normally functioning fish ponds, turbidity, color and SS are positively correlated and each of these parameters were negatively correlated with transparency [31]. Suspended particles limit the penetration of light into water which reduces transparency. Water is good for fish farming when the SS are less than or equal to $30 \mathrm{mg} /$ $\mathrm{L}$ and the transparency is between 15 and $30 \mathrm{~cm}[29,31]$. The values of SS and transparency observed in the peasant ponds were similar to those described in a pond fertilized with organic matter in the same region in Cameroon [20].

Indeed, this breeding cycle was disturbed by torrential rains causing a complete mixing of the pond water and the prolonged trampling of the bottom of the basin by pigs that escaped from the neighboring piggery [32-33]. Added to these environmental stresses, is the shallow depth of the water that constantly caused mixing and finally an increase in the behavior of fish during the search for food (the case of tilapia that digs the mud to sort out its preferential foods) [34].

Among the peasant ponds, $\mathrm{O}_{2}$ value was higher in $\mathrm{E} 3$, due to photosynthetic activity of macrophytes which invaded the bottom of this pond as early as the second month and remained there until the $6^{\text {th }}$ breeding month. The multiple environmental stresses that have occurred in the fish farm during the breeding cycle coupled with the lack of rapid intervention on the part of the farmer would be the cause of the lethal doses of oxygen recorded some times in the ponds [35-36]. This was the case of E1 where the combined action of torrential rains and slow degradation of the fertilizer used (Pennisetum purpureum) lead to the very low availability of mineral elements that could cause photosynthesis and the momentary and unquantified spill of pig manure on the $7^{\text {th }}$ and $8^{\text {th }}$ months of breeding. These rains did not only direct the stream feeding the ponds towards E3 but they degraded the bank between E2 and E3. This caused the spill of E3 waters into those of E2 without control. However, the fish farmer was only able to completely rectify this disorder at the twelfth week of breeding. This period was therefore marked by leaching of the bottom waters of ponds E3 and E2 and a strong reduction of the algae that colonized the environment [33].

Generally, calcium hardness levels were relatively low in all ponds compared to fish standards $\left(>30 \mathrm{mg} / \mathrm{L} \mathrm{CaCO}_{3}\right.$ ) [37]. These low values could be justified by the absence of calcareous soil in the study area. The high values obtained in ET compared to the peasant ponds were due to the inflow of quicklime received by this water body during breeding to enhance organic fertilization. The calcium hardness values recorded in ET are favorable to the development of fish. The average levels of total alkalinity obtained were generally within the range $\left(47-100 \mathrm{mg} / \mathrm{L}\right.$ of $\left.\mathrm{CaCO}_{3}\right)$ in fish ponds [31]. Peasant ponds ranged from $33 \mathrm{mg} / \mathrm{L} \mathrm{CaCO}_{3}$ to $46.7 \mathrm{mg} / \mathrm{L}$ $\mathrm{CaCO}_{3}$ but remained above the $20 \mathrm{mg} / \mathrm{L} \mathrm{CaCO}_{3}$ value acceptable for fish production under conditions of $\mathrm{pH}$ greater than or equal to 6.5 [37]. Values of alkalinity less than 20 $\mathrm{mg} / \mathrm{L}$ of $\mathrm{CaCO}_{3}$ recorded from the tenth week of breeding during start-up in ponds could be justified by the incomplete dissolution of $\mathrm{CO}_{2}$ in water [32, 38].

Regardless of the water body, the $\mathrm{pH}$ values remained within the range (5-9) which fish can tolerate [37, 39]. However, the waters of pond ET were mostly basic and favorable to the growth and health of cultured fish; those of the peasant ponds were the most acidic with low values $(<$ 6.5) recorded throughout the three first months. Indeed, significant differences in calcium hardness, alkalinity and $\mathrm{pH}$ were recorded during start-up between the peasant ponds and pond ET. Such acidic $\mathrm{pH}$ in low alkaline water $(<20 \mathrm{mg} / \mathrm{L})$ is harmful for fish. In high concentrations ( $>1 \mathrm{mg} / \mathrm{L})$ ammonia is toxic to consumers including fish. In addition, the toxicity threshold for this element varies with $\mathrm{pH}$ and begins to be critical for fish when the $\mathrm{pH}$ is greater than 8 [31].

The availability of nitrogen and phosphorus in the water column for photosynthetic processes is a function of the total alkalinity of the water [29]. Below a certain threshold $(<20$ $\left.\mathrm{mg} / \mathrm{L} \quad \mathrm{CaCO}_{3}\right)$, nitrogen fixation by sediment microorganisms, high concentrations of $\mathrm{NH}_{4}^{+}$as well as phosphorus precipitation are favored to the detriment of photosynthesis [20, 38]. Positive correlations were recorded between alkalinity and orthophosphate in the peasant ponds during the start-up. Values of alkalinity lower than $20 \mathrm{mg} / \mathrm{L}$ of $\mathrm{CaCO}_{3}$ recorded in ponds are not only unfavorable to the nutrition of tilapias and catfish [37] but are also favorable to the fixation of nitrogen by microorganisms in sediment, the 
precipitation of phosphorus, all this to the detriment of photosynthesis [28].

In terms of the physicochemical parameters analysis and the interactions between these parameters, the conditions that were unfavorable to the growth of tilapias and catfish were most frequent in E3, followed by E1 and finally E2. The Spearman correlation test revealed that pond ET had the greatest number of correlations between physicochemical parameters and was associated with the highest values of productivity parameters namely calcic hardness, alkalinity, temperature, $\mathrm{pH}$, oxygen and MES. This confirms that the follow-up granted to this pond at the beginning which favored the abiotic equilibrium allowing good nutrition of zooplankton and the fish as well as providing an acceptable functioning of this medium during all the breeding period. It results from these analysis that the different values of the main physicochemical parameter found in the studied water bodies were characteristics of a mesotrophic (E1 and E2), eutrophic (ET) and oligomesotrophic (E3) media as classified by [40]. Such variations in physico-chemistry affect the composition of zooplankton in fish ponds.

Concerning the biological aspect, Rotifers were the most abundant in all the ponds due to unstable environmental conditions in water which lead to their rapid reproduction. In fact, reproduction of rotifers is sexual and growth is a function of the quality and quantity of food and temperature $[15,16,20$, 41]. However, the low abundance of rotifer recorded in E3 during the study period is justified by the combined effect of predation exerted by tilapia fingerlings and the carnivorous copepod Mesocyclops salinus which grows and reproduces easily in low nutrient milieu. In addition, Mesocyclops salinus is a potential predator of rotifers and small Cladocerans, it regularly occupies the same ecological niche as fish fry with which it competes for food [14].

This high abundance coupled with the high biomass found in ET is justified by the fact that the zooplankton of this pond would have been fed by browsing the algae preferentially, the physicochemical conditions of the medium $(\mathrm{pH}>6$, alkalinity $>47 \mathrm{mg} \mathrm{CaCO}_{3} / \mathrm{L}$, temperature $>25^{\circ} \mathrm{C}$ ) were favorable to photosynthetic activity and also to zooplankton growth and reproduction [31, 42]. On the other hand, the very low abundances and biomass recorded in E3 were justified by the effect of competition for nutrients between macrophytes and phytoplankton that invaded the bottom of this pond, coupled with the slowdown of nutrition in zooplankton following the acidity of the water and the various environmental stresses suffered by this pond.

The alternation of numerical dominance observed in E1 and E3 between adult Copepods and Cladocerans further explains the effect of low fertilization to the water body. Thus the dominance of Copepods over Cladocerans observed throughout this study in E1 and E3 is supported by other works which point out that not only are Copepods able to escape predation, but also they have the k-type strategy: have a strong ability to grow and reproduce compared to daphniids in environments with limited food resources [14, 20, 43]. Also, a disturbance in the environment can cause profound changes in the structure of the population. These upheavals can be manifested by a change in the relative dominance of the species, by faunistic and floristic substitutions, and even by the complete disappearance of an element or all the biocoenosis if the disturbance is too strong $[20,44]$.

With regards to the spatio-temporal contribution of different taxa of zooplankton to the biomass recorded during the study, it is variable and this variability is a function in each water body, of the environmental stresses (rain that the water body undergoes and the quality of intervention that the farmer brings to the water when the need arises. It appears that the rapid intervention by the farmer in pond ET when need arises, where necessary to improve the physicochemical conditions of the environment, which in turn were favorable to the nutrition and reproduction of these species.

\section{Conclusion}

This work shows that in addition to the natural enrichment due to the contributions of the watershed, when a pond undergoes an acceptable fertilization, whether organic or mineral, it must follow a rigorous daily control within the first three months of breeding by the farmer to induce a variation in species richness, zooplankton abundance and therefore a variation in zooplankton biomass. We can therefore suggest the hypothesis that a good fertilization of the fish pond coupled with a routine control that ensures the maintenance of physicochemical parameters in the fish standards, greatly improve the productivity of the pond. In addition, researchers should be very vigilant when dealing with piscicultural ponds in order to better include/understand the ecology of this particular type of ecosystem; and to reduce the expenditure by always associating to each pond, the breeding of domestic animals (most effective within the framework of this work being the breeding of pigs) that must be installed on the bank of the pond and the cleaning of the water channel. However, the associated animals must be suitably nourished, the zoo technical standards should envisage a ration day for the labourer at least $6 \%$ of the net weight of the animal.

\section{References}

[1] Dussart B. H., 1986. Limnologie. Ed. Gauthiers Villars, Paris.

[2] Lair N., Reyes-Marchant P. \& Jacquet V., 1998. Développement du phytoplankton, des ciliés et des rotifers sur deux sites de la Loire moyenne (France) en période d'étiage. Annls. Limnol., 34, 35-48.

[3] Haberman J., 1998. Zooplankton of lake Vörtsjärv. Annls. Limnol., 28, 49-65.

[4] Piasecki W., Goodurin A. E., Eiras J. C. \& Nowak B. F., 2004. Importance of Copepoda in Freshwater Aquaculture. Zoological Studies, 43, 193- 205. 
[5] Amoros C., 1984. Crustacés cladocères. In: Introduction pratique à la systématique des organismes des eaux continentales françaises 5, Bull. Mens. Soc. Lin. Lyon, 3, 5363 .

[6] Zébazé Togouet S. H., Njiné T., Kemka N., Nola M., Foto Menbohan S., Niyitegeka D., Ngassam P. et Boutin C., 2006. Composition et distribution spatio-temporelle des protozoaires ciliés dans un petit lac hypereutrophe du Cameroun (Afrique Centrale). Rev. Sci. Eau, 19: 151-162.

[7] FAREC, 2019. (Fédération Aquacole de la Région Centre). La filière pisciculture d'étang de la région Centre Val de Loire au Salon de l'Agriculture, 2019; La pisciculture: passions et tradition d'avenir, $4 \mathrm{p}$.

[8] Blé M. C., Vanga Adja F., Assi Kaudhjis P. J., Alla Yao L., Efolé Ewoukem T., Kouassi Adjoua F., Coulibaly Kanidana S., Mikolasek O., 2015. Environnement socio-économique des exploitants piscicoles du Centre-Ouest et du Sud-Ouest de la Côte D'Ivoire. F. Tech. \& Doc. Vulg.: 12-17- Volume spécial.

[9] Agadjihouede H., Chikou A., Montchowui E. et Laleye P., 2014. Effet de la densité initiale de mise en charge sur la survie et la croissance des larves d'Heterobranchus longifilis (Valenciennes, 1840) élevées en bassins fertilisés. Journal of Applied Biosciences, 84: 1997-5902.

[10] MINEPIA, 2008. Stratégie pour un développement durable de l'aquaculture au Cameroun. Rapport de séminaire, $4 \mathrm{p}$.

[11] FAO, 2016. La situation mondiale des pêches et de l'aquaculture: contribuer à la sécurité alimentaire et à la nutrition de tous. Rome 224 p.

[12] Blé M. C., Assi Kaudhjis P. J., Vanga Adja F., Efolé Ewoukem T., Alla Yao L., Mikolasek O., Amian Atsé F., Kouassi Adjoua F., Coulibaly Kanidana S., Wandan Eboua N., 2015. Pratiques piscicoles dans le Centre-Ouest et le Sud-Ouest de la Côte D’Ivoire. F. Tech. \& Doc. Vulg.: 3-11- Volume spécial.

[13] MAPA (Ministère de l'Agriculture, des pêcheries et de l'Alimentation), 2016. Aquaculture, Document d'information spécialisée. Lois et règlements relatifs à l'Aquaculture en eau douce; Agriculture, Pêcheries et Alimentation Québec; 16 p.

[14] Zébazé Togouet S. H., Dakwen J. P., Foto Membohan S., Banga Medjo M. P., Essomba Biloa R. E. and Njiné T., 2015. Influence d'un enrichissement sommaire sur la biomasse zooplanctonique des étangs piscicoles in situ en zone tropicale (Cameroun- Afrique Centrale). European Journal of Scientific Research, 131 (1): $22-40$.

[15] Pourriot R., 1968. Rotifères du lac Tchad. Bulletin IFAN. 30, 471-496.

[16] Green J., 1977. Dwarfing of rotifers in tropical crater lakes. Arch. Hydrobiol. Beich, 8, 232-236.

[17] Zébazé Togouet S. H., 2000. Biodiversité et dynamique des populations de Zooplancton (Ciliés, Rotifères, Cladocères et Copépodes) du Lac Municipal de Yaoundé (Cameroun). Thèse Doctorat $3^{\text {eme }}$ cycle, Université de Yaoundé I, Cameroun, 175p + Annexes.

[18] Rodier J., Legube B., Merletet N., Brun R., Mialocq J. C., Leroy P., Houssin M., 2009. L'analyse de l'eau: eaux naturelles, eaux résiduaires et eau de mer. Chimie, physicochimie, interprétation des résultats. ( $9^{\mathrm{e}}$ édition), Paris, Dunod. $1579 \mathrm{p}$.
[19] Besnard A. \& Salles J. M., 2010. Suivi scientifique d'espèces animales. Aspects méthodologiques essentiels pour l'élaboration de protocoles de suivis. Note méthodologique à l'usage des gestionnaires de sites Natura 2000, Rapport DREAL PACA, Pôle Natura 2000.

[20] Dakwen J. P., Zébazé Togouet S. H., Tuekam Kayo R. P., Djeufa Heuchim C., Nziéleu Tchapgnouo J. G., Foto Menbohan S., Njiné T., 2015. Physico-chemistry characterization and zooplankton specific diversity of two fishponds in Yaoundé (Cameroon, Central Africa). Journal of Biodiversity and Environmental Sciences, 6 (2): 16-30

[21] Pourriot R., 1980. Rotifères. In: IDT ORSTOM (Eds.), Flore et faune aquatiques de l'Afrique sahélo-soudanienne I (pp. 219-244). Paris.

[22] Fernando C. H., 2002. Introduction in a guide to tropical fresh water zooplankton. Identification ecology and impact on fisheries. Ed. C. H. Fernando, Leiden (Netherlands).

[23] Dussart B. H. \& Defaye D., 1995. Copepoda: Introduction to the copepoda. Guide to the identification to the Microinvertebrates of the continental waters of the world 7. Ed. H. J. Dumont, S. P. B., Acad. Publ., The Hague.

[24] Legende L. \& Watt W. D., 1972. On a rapid technique for plankton enumeration. Annls. Inst. Oceanogr., XLVIII, 173177.

[25] Sime-Ngando T., Hartmann H. J. \& Groliere C. A., 1990. Rapid quantification of planktonic ciliates: comparison of improved live counting with other methods. Appl. Environ. Microbiol., 56: 2234-2242.

[26] Dumont H. J., Van de Velde I. \& Dumont S., 1975. The dry weight estimate of biomass in a selection of Cladocera, Copepoda and Rotifera from the plankton, periphyton and benthos of continental waters. Oecologia, 19, 75 - 97.

[27] Zébazé Togouet S. H., Njiné T., Kemka N., Nola M., Foto Menbohan S., Monkiedje A., Niyitegeka D., Simé-Ngando T. \& Jugnia L. B., 2005. Variations spatiales et temporelles de la richesse et de l'abondance des rotifères (Brachionidae et Trichocercidae) et des cladocères dans un petit lac artificiel eutrophe situé en zone tropicale. Rev. Sci. Eau, 18, 485-506.

[28] Viner A. B., 1969. The chemistry of the water of lake George, Uganda. Verh. Int. Ver. Limnol., 17, 289-296.

[29] Billard R. et Marie D., 1980. La qualité des eaux de l'étang de pisciculture et son contrôle. In: Billard R. (Ed.), La pisciculture en étang, INRA Publ., Paris (France), Pp 107-127.

[30] FAO (Food and Agricultural Organisation), 2018. La situation mondiale des pêches et de l'aquaculture. Atteindre les objectifs du développement durable. Rapport annuel, 28 p.

[31] Schlumberger O., 2002. Mémento de la pisciculture d'étang,

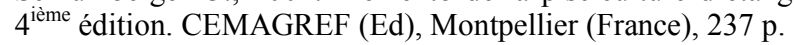

[32] Efole Ewoukem T., Aubin J., Tomedi Eyango M., Mikolasek O., Corson M. S., Tchoumboué J., Van der Werf H. M. G. et Ombredane D., 2010. Environmental impacts of farms integrating aquaculture and agriculture in Cameroon. Proceeding of LCAfood 2010, (1): 375-380

[33] Mikolasek O., 2003. Forces et faiblesses de la pisciculture de la vallée du Ribeira, Etat de San Paulo, Brésil: une typologie pour éclairer les pratiques des pisciculteurs. Mémoire de DEA INAP-G, Paris (France), 26 p. 
[34] Dabbadie L., Lazard J. et Oswald M., 2002. Pisciculture et élevages non conventionnels: Pisciculture, Mémento de l'Agronome, CIRAD-GRET (Ed), Ministère des Affaires étrangères (France), 2: 1571-1651

[35] Mikolasek O., et Lazard J., 1999. La pisciculture continentale en milieu tropical. In: actes de colloque: Réalités et perspectives de développement de l'aquaculture dans le SudOuest de l'Océan Indien - Iles de la Réunion Saint Leu les 31 mai au 3 juin 1999, ARDA - Aquaculture, Pp 32- 41.

[36] Mikolasek O., Guérin G., Lopez A., Khuyen T. D., Huy P. T., Dien N. T., 2006. Local fish farming practices and a typology of farms based on organic matter intake management. In: Orphyre V., Coi N. Q. (Eds.), Pig Production Development, Animal Waste Management and Environment Protection: A Case Study in Thai Binh Province, Northern Vietnam. PRISE Publications, France, 107-125

[37] Pouomogne V., 1998. Pisciculture en milieu tropical africain: comment produire du poisson à coût modéré. CEPID/Coopération Française, Yaoundé (Cameroun), Presses Universitaire d' Afrique, $236 \mathrm{p}$.

[38] Morin R., 2012. «Qualité de l'eau requise pour l'élevage des salmonidés ». Document d'information DADD-14. Ministère de l'agriculture, des Pêcheries et de l'Alimentation $25 \mathrm{p}$. http:// www. mapaq. gouv. qc. $\mathrm{Ca} / \mathrm{Fr} / \mathrm{Peche}$
[39] Tomedi Eyango M., Efolé Ewoukem T., Blé M. C., Ndzana B. E. B., Songmo B. L., Nyamsi Tchatcho N. L., Mikolasek O., Tchoumbougnang F., 2015. Rizipisciculture: voie d'intensification écologique des systèmes piscicoles extensifs. F. Tech. \& Doc. Vulg.: 18-23- Volume spécial.

[40] Wurtz W. A. et Durborow R. M., 1982. Interactions of pH, carbon dioxide, alkalinity and hardness in fish ponds, southern Regional Aquaculture center, U.S., Publication $N^{\circ} 464,4$ p.

[41] Côté R., Bussières D., Desgagnés P., 2019. Spatio-temporal distribution of phytoplankton and zooplankton in Lake SaintJean (Quebec), Hydro-electric reservoir; Rev. Sci. Eau, 15 (3): 597-614.

[42] Ustun F., Bat L., Sahin F., 2019. Composition, abundance and biomass of Mesozooplankton in the South western Black Sea Along the coast of Igneada, Turkey. Biologia. DOI: 10.2478/s11756-019-00219-w

[43] Mac Naugit D. C., 1975. A hypothesis to explain the succession from calanoids to cladocerans during eutrophication. Verh. Int. Ver. Limnol., 19, 724-731

[44] Tuffery G., 1980. Incidences écologiques de la pollution des eaux courantes Révélateurs biologiques de la pollution. In: Gauthier-Villars (Ed.), Paris. La pollution des eaux continentales. Incidence sur la biocénose aquatique (Pp. 243280). 